\title{
Histopathological Injuries, Ultrastructural Changes, and Depressed TLR Expression in the Small Intestine of Broiler Chickens with Aflatoxin $B_{1}$
}

\author{
Fengyuan Wang ${ }^{1,+}$, Zhicai Zuo ${ }^{1,+}$, Kejie Chen ${ }^{2,+}$, Caixia Gao ${ }^{1,+}$, Zhuangzhi Yang ${ }^{3}$, \\ Song Zhao ${ }^{1}{ }^{\circledR}$, Jianzhen $\mathrm{Li}^{4}{ }^{4}$, Hetao Song ${ }^{1}$, Xi Peng ${ }^{5, *}$, Jing Fang ${ }^{1, *}$, Hengmin Cui ${ }^{1}$, \\ Ping Ouyang ${ }^{1}$, Yi Zhou ${ }^{6}$, Gang Shu ${ }^{1}$ and Bo Jing ${ }^{1}$ \\ 1 College of Veterinary Medicine, Sichuan Agricultural University, Chengdu 611130, China; \\ wfy_sccd@163.com (F.W.); zzcj1@126.com (Z.Z.); m15009661712@163.com (C.G.); \\ bingozhaosong@163.com (S.Z.); sht854844223@sina.com (H.S.); cuihengmin2008@sina.com (H.C.); \\ ouyang.ping@163.com (P.O.); dyysg2005@sicau.edu.cn (G.S.); jingbo@sicau.edu.cn (B.J.) \\ 2 School of Public Health, Chengdu Medical College, Chengdu 610500, China; ckj930@126.com \\ 3 Animal Research Institute, Chengdu Academy of Agriculture and Forestry Sciences, Chengdu 611130, \\ China; yangzhuangzhi8@163.com \\ 4 Department of Preventive Veterinary, Chengdu Agricultural College, Chengdu 611130, China; \\ jianzhenli2006@163.com \\ 5 College of Life Sciences, China West Normal University, Nanchong 637002, China \\ 6 Life Science Department, Sichuan Agricultural University, Yaan 625014, China; 13981616210@139.com \\ * Correspondence: pengxi197313@163.com (X.P.); fangjing4109@163.com (J.F.); Tel.: +86-139-0809-3903 (X.P.); \\ +86-130-5657-7921 (J.F.) \\ + These authors contributed equally to this work.
}

Received: 30 January 2018; Accepted: 18 March 2018; Published: 21 March 2018

\begin{abstract}
To explore $\mathrm{AFB}_{1}$-induced damage of the small intestine, the changes in structure and expression of TLRs (Toll-like Receptors) in the small intestine of chickens were systematically investigated. Ninety healthy neonatal Cobb chickens were randomized into a control group $\left(0 \mathrm{mg} / \mathrm{kg} \mathrm{AFB}_{1}\right)$ and an $\mathrm{AFB}_{1}$ group $\left(0.6 \mathrm{mg} / \mathrm{kg} \mathrm{AFB}_{1}\right)$. The crypt depth of the small intestine in the $\mathrm{AFB}_{1}$ group was significantly increased in comparison to the control chickens, while the villus height and area were evidently decreased, as well as the villus:crypt ratio and epithelial thickness. The histopathological observations showed that the villi of the small intestine exposed to $\mathrm{AFB}_{1}$ were obviously shedding. Based on ultrastructural observation, the absorptive cells of small intestine in the $\mathrm{AFB}_{1}$ group exhibited fewer microvilli, mitochondrial vacuolation and the disappearance of mitochondrial cristae, and junctional complexes as well as terminal web. Moreover, the number of goblet cells in the small intestine in the $\mathrm{AFB}_{1}$ group significantly decreased. Also, $\mathrm{AFB}_{1}$ evidently decreased the mRNA expression of TLR2-2, TLR4, and TLR7 in the small intestine. Taken together, our study indicated that dietary $0.6 \mathrm{mg} / \mathrm{kg} \mathrm{AFB}$ could induce histopathological injuries and ultrastructural changes, and depress levels of TLR mRNA in the chicken small intestine.
\end{abstract}

Keywords: aflatoxin $\mathrm{B}_{1}$; small intestine; histopathological lesions; ultrastructural changes; toll-like receptors

Key Contribution: The aim of this paper is to comprehend the damaged innate immunity of small intestine induced by AFB1. The results could provide important insights for the future studies of AFB1 related to animals and humans. 


\section{Introduction}

Aflatoxins, secondary metabolites produced by some Aspergillus species [1,2], are important mycotoxins since about 0.5 to 4.5 billion people are exposed to high levels of aflatoxins. [3,4]. Aflatoxin $\mathrm{B}_{1}\left(\mathrm{AFB}_{1}\right)$ is the main source and most toxic type of aflatoxins [5]. The liver is the main target organ for aflatoxins [6,7]. The negative effects of $\mathrm{AFB}_{1}$ have also been well-documented, including reduced performance, decreased immune system function, and increased susceptibility to diseases in several animal species [8-10].

Conversion and absorption of food components mainly take place in the gastrointestinal tract. Normal nutrient supply is supported by several factors, including absorptive surfaces, residing microorganisms, and host-derived physiological processes [10]. Meanwhile, the intestinal mucosa is continually exposed to a series of antigens, especially the bacterial antigens. Intestinal epithelial cells (IECs) act as a defense system between the intestinal lumen and the lamina propria [11]. The entire structure and function of IECs, which possess tight junction and goblet cells producing mucus, prevent luminal antigens from translocating to the subepithelial tissue [12,13].

The immunotoxicity of $\mathrm{AFB}_{1}$ to the intestine has drawn research attention. It has been reported that $\mathrm{AFB}_{1}$ decreased the proportion of T-cell subset and number of IgA ${ }^{+}$cells in the small intestine of chickens $[14,15]$. The literature, however, is scanty and controversial as to the effects of $\mathrm{AFB}_{1}$ on the morphology and histopathology of the gastrointestinal tract [10]. After exposure to $0.02 \mathrm{mg} / \mathrm{kg}$ or $0.7 \mathrm{mg} / \mathrm{kg} \mathrm{AFB}$ for three weeks, the density (weight/length) of the whole intestine in chickens was evidently decreased [16,17]. Grozeva et al. found that $0.5 \mathrm{mg} / \mathrm{kg} \mathrm{AFB}_{1}$ induced generalized hyperaemia and mononuclear cell infiltration in the small intestine of broilers within the 42 days of an experiment [18], but, at a higher level of $4 \mathrm{mg} / \mathrm{kg}$ diet, Ledoux et al. revealed no histological damage to male broilers' small intestine after a three-week exposure [19].

The pattern recognition receptors (PRRs) have been confirmed to be associated with immunity, inflammation, and cancer [20]. TLRs, one type of the PRRs, have been studied in different areas, including immunotoxicity, inflammation, oxidative stress and cell survival [21]. A few in vitro studies reported that mycotoxins affected TLRs' expression or TLRs-associated pathways. Mixed aflatoxins B and G up-regulated TLR2 and TLR4 transcript in human peripheral blood mononuclear cells [21], while deoxynivalenol led to the inhibition of TLR-MyD88 signaling in RAW264 cells [22].

The gastrointestinal tract is the first organ by which $\mathrm{AFB}_{1}$ comes into the body of human and animals; thus, compared with other organs, this toxin should exert greater impacts on the small intestine. However, the effects of $\mathrm{AFB}_{1}$ on the small intestine are often neglected and inconclusive [10]. And the doses and exposure time of $\mathrm{AFB}_{1}$ to cause histopathological changes of the intestine were controversial in chickens [16-19]. Our team's research has shown that $0.15 \mathrm{mg} / \mathrm{kg}$, $0.3 \mathrm{mg} / \mathrm{kg}$ and $0.6 \mathrm{mg} / \mathrm{kg} \mathrm{AFB}_{1}$ could cause obvious toxic effects on chichen immune organs with dose-response $[9,23,24]$. In our previous study, $0.3 \mathrm{mg} / \mathrm{kg} \mathrm{AFB}$ decreased jejunal villus height, villus height/crypt ratio, and induced shedding of epithelial cells on the tip of chicken jejunal villus from 7 to 21 days of age [25]. To observe whether $0.6 \mathrm{mg} / \mathrm{kg} \mathrm{AFB} 1$ would cause more serious damage to the whole small intestine in the same exposure time, we determined to use a higher dose $\left(0.6 \mathrm{mg} / \mathrm{kg} \mathrm{AFB}_{1}\right)$ to do the further systemic research. Furthermore, TLRs play vital roles in the innate immune system, and several studies on the effects of different mycotoxins on TLR gene expression were focused on TLR2, TLR4 and TLR7 [21,22,26-28]. Thus, these three TLRs were chosen for this research in order to compare the $\mathrm{AFB}_{1}$-induced effects on TLR2, TLR4 and TLR7 with other mycotoxins.

Therefore, this research was conducted to systematically study the histopathological damages and TLR expression in the small intestine of chickens caused by dietary $0.6 \mathrm{mg} / \mathrm{kg} \mathrm{AFB}$ through multiple technologies, such as hematoxylin and eosin staining, histological chemistry, microscopic analyses of the villus, crypt depth and goblet cells, the mucosal epithelium observation by transmission electron microscope, and TLR2, TLR4, and TLR7 mRNA expression by qRT-PCR. 


\section{Results}

\subsection{Morphological Measurements in the Small Intestine}

At three different time points, compared with the control group, the villus height of duodenum in the $\mathrm{AFB}_{1}$ group was significantly decreased $(p<0.05$ or $p<0.01)$, while the villus width was significantly increased ( $p<0.05$ or $p<0.01$ ). Overall, the villus area of the duodenum in the $\mathrm{AFB}_{1}$ group was evidently decreased $(p<0.01)$. Although the crypt depth of duodenum in the $\mathrm{AFB}_{1}$ group was significantly increased $(p<0.01)$, the villus:crypt ratio in the $\mathrm{AFB}_{1}$ group dropped significantly $(p<0.01)$. Moreover, the epithelial thickness of duodenum in the $\mathrm{AFB}_{1}$ group significantly declined $(p<0.05)$ (Figure 1).
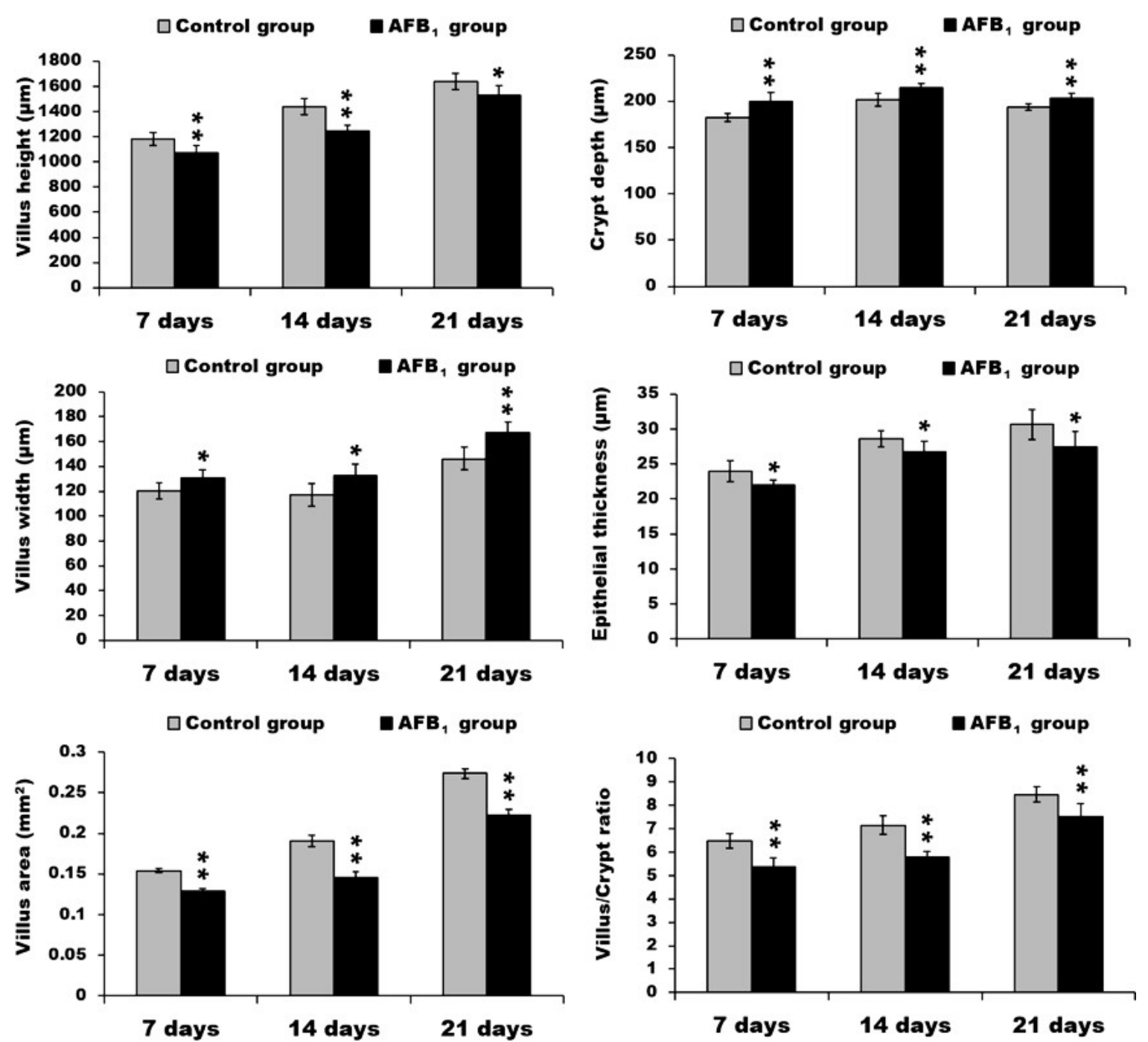

Figure 1. The data of villus height, crypt depth, villus width, epithelial thickness, villus area, and villus/crypt ratio in the duodenum. ${ }^{*} p<0.05,{ }^{* *} p<0.01$.

Compared with the control group, the jejunum of the $\mathrm{AFB}_{1}$ group exhibited lower villus height, width, and area $(p<0.05$ or $p<0.01)$. The jejunal crypt depth in the $\mathrm{AFB}_{1}$ group, moreover, was significantly increased $(p<0.05$ or $p<0.01$ ), in addition, the villus:crypt ratio was evidently lower $(p<0.01)$. At all three time points, the epithelial thickness of jejunum in the $\mathrm{AFB}_{1}$ group was significantly decreased $(p<0.05$ or $p<0.01$ ) (Figure 2 ). 

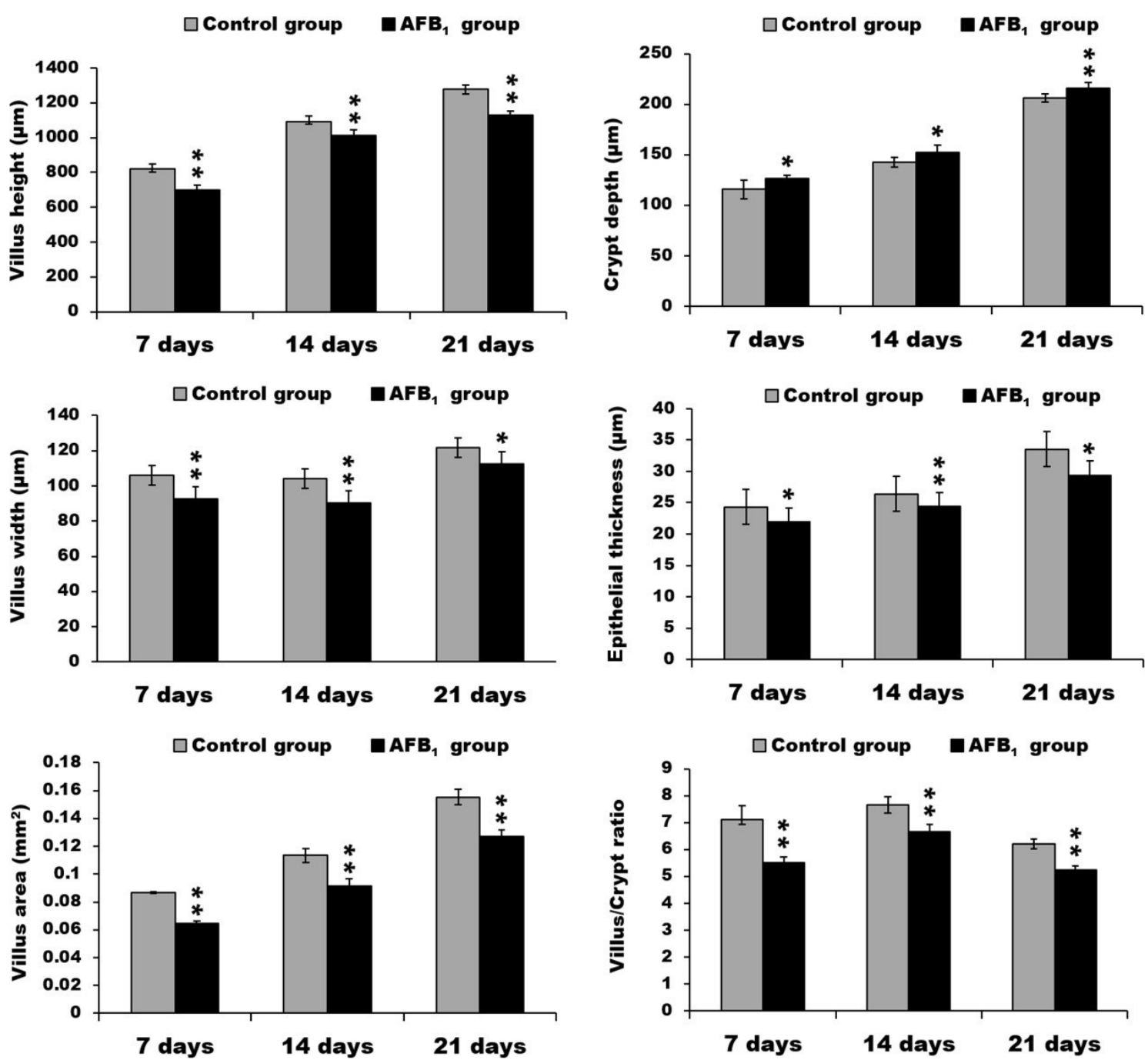

Figure 2. The data of villus height, crypt depth, villus width, epithelial thickness, villus area, and villus/crypt ratio in the jejunum. ${ }^{*} p<0.05,{ }^{* *} p<0.01$.

Compared with the control group, the ileum of broilers exposed to $\mathrm{AFB}_{1}$ showed lower villus height, width, and area $(p<0.05$ or $p<0.01)$. The ileac crypt depth in the $\mathrm{AFB}_{1}$ group, moreover, was significantly increased $(p<0.05$ or $p<0.01)$, and the villus:crypt ratio had evidently dropped $(p<0.01)$. On day 14, the epithelial thickness of the ileum in the $\mathrm{AFB}_{1}$ group was significantly decreased $(p<0.05)$ (Figure 3). 

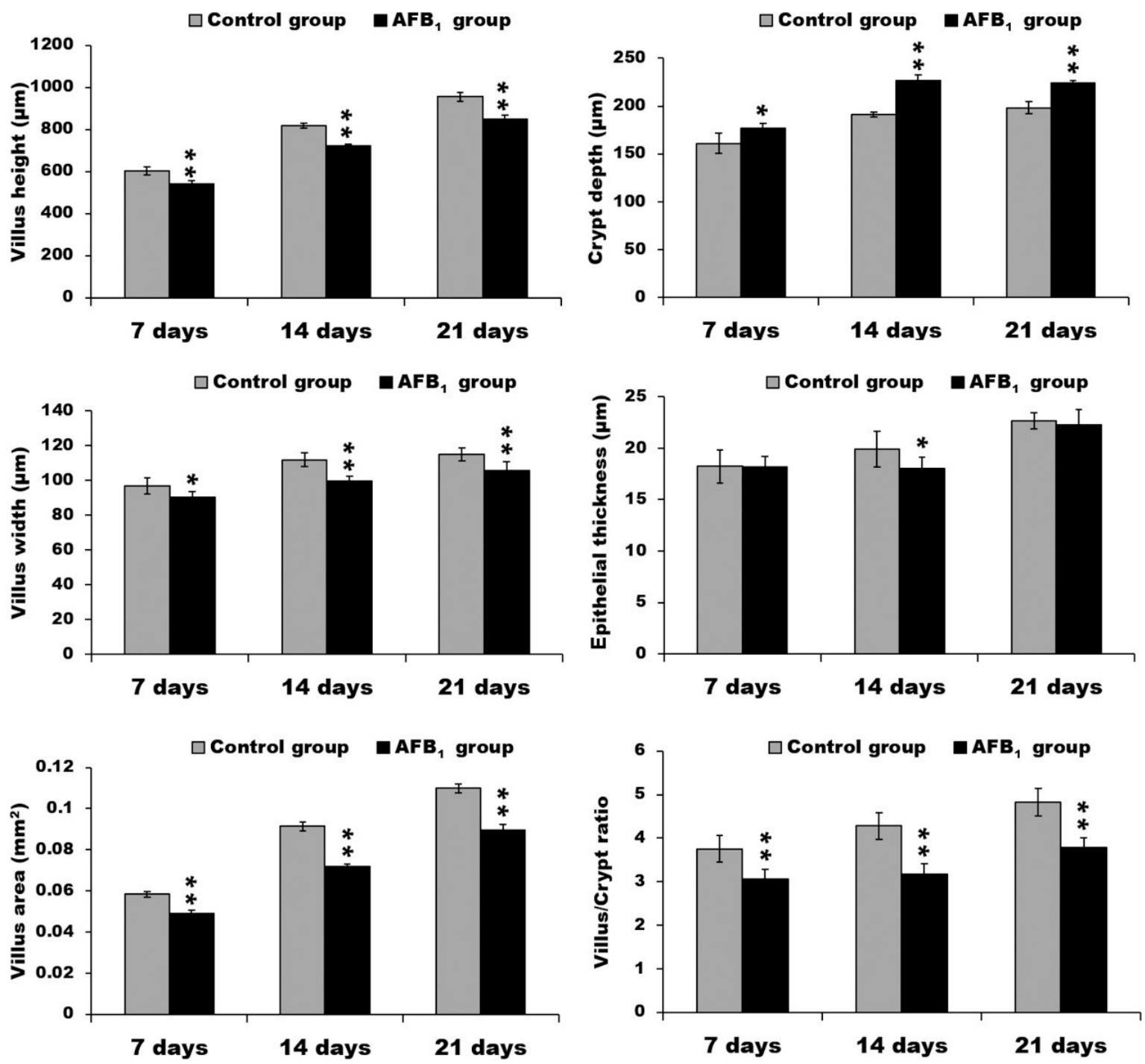

Figure 3. The data of villus height, crypt depth, villus width, epithelial thickness, villus area, and villus/crypt ratio in the ileum. ${ }^{*} p<0.05,{ }^{* *} p<0.01$.

\subsection{Histopathological Analysis}

The apical epithelia of villi in the small intestine in the $\mathrm{AFB}_{1}$ group were shedding (Figure 4). No other obvious pathological damage to the chicken intestine in the $\mathrm{AFB}_{1}$ group was observed. 

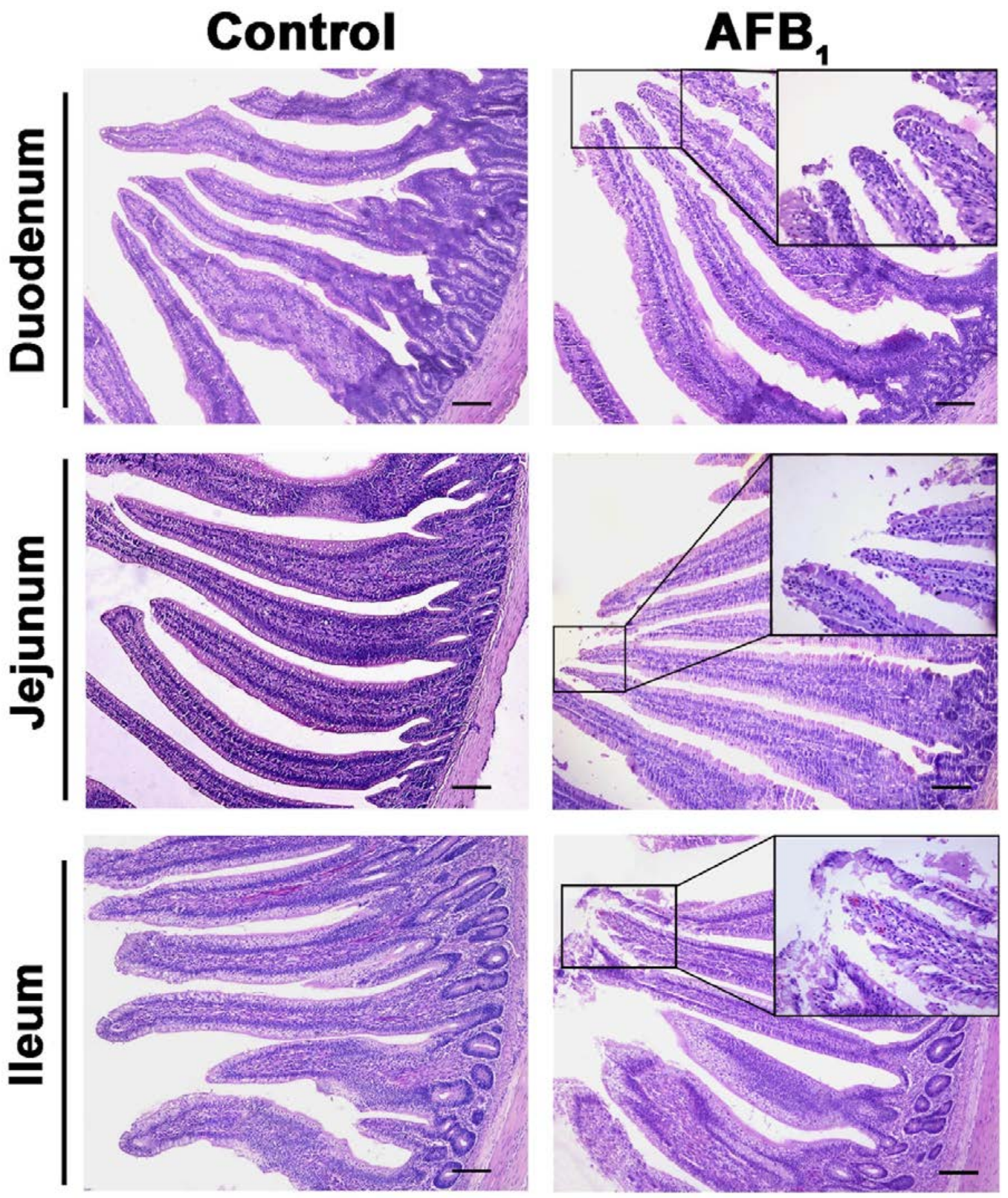

Figure 4. The representative microstructure of intestinal villi at 21 days of age. Note: The enlarged box shows the shedding of epithelial cells; H.E. stain, scale bar $=200 \mu \mathrm{m}$.

\subsection{Ultrastructure Changes}

The mucosal epithelium of the small intestine consists predominately of absorptive cells and goblet cells (Figure 5). In the duodenum, jejunum, and ileum of the control group on day 21 of the experiment, there are closely packed microvilli in the apical border of absorptive cell. Also, abundant mitochondria with normal ultra-structure were located in the apical cytoplasm of this cell. Junctional complexes including tight junction, intermediate junction, and desmosome were distributed between the epithelial cells at the luminal surface. A terminal web containing many micro-filaments was well organized under the microvilli.

In the duodenum of the $\mathrm{AFB}_{1}$ group on day 21, reduced mitochondrial cristae and mitochondrial vacuolation and lysis of mitochondrial contents in the apical portion of some absorptive cells were the most obvious ultrastructural pathological changes (Figure 5). 
In the jejunum of the $\mathrm{AFB}_{1}$ group, the microvilli on the surface of some absorptive cells were completely shed, and the junctional complexes and terminal web were partly or completely disappeared. In addition, the number of mitochondria had evidently decreased (Figure 5).

Also, the microvilli of some ileac absorptive cells in the $\mathrm{AFB}_{1}$ group on day 21 were fewer or shorter, or even completely shed, and the junctional complexes and terminal web had partially or entirely disappeared. Finally, fewer mitochondria, a decreased electron density, and lysis contents of apical cytoplasm were observed (Figure 5).

\section{Control}
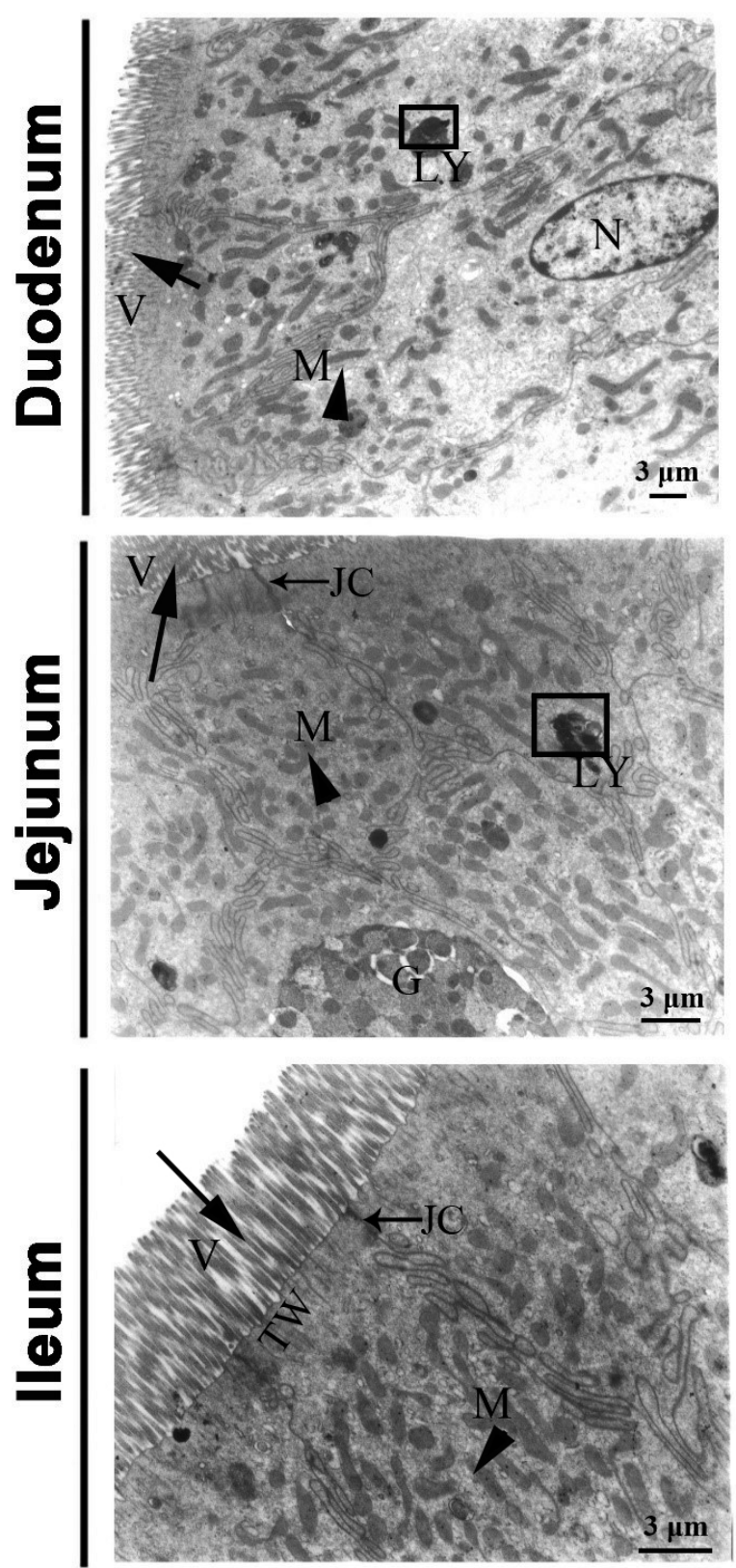

AFB
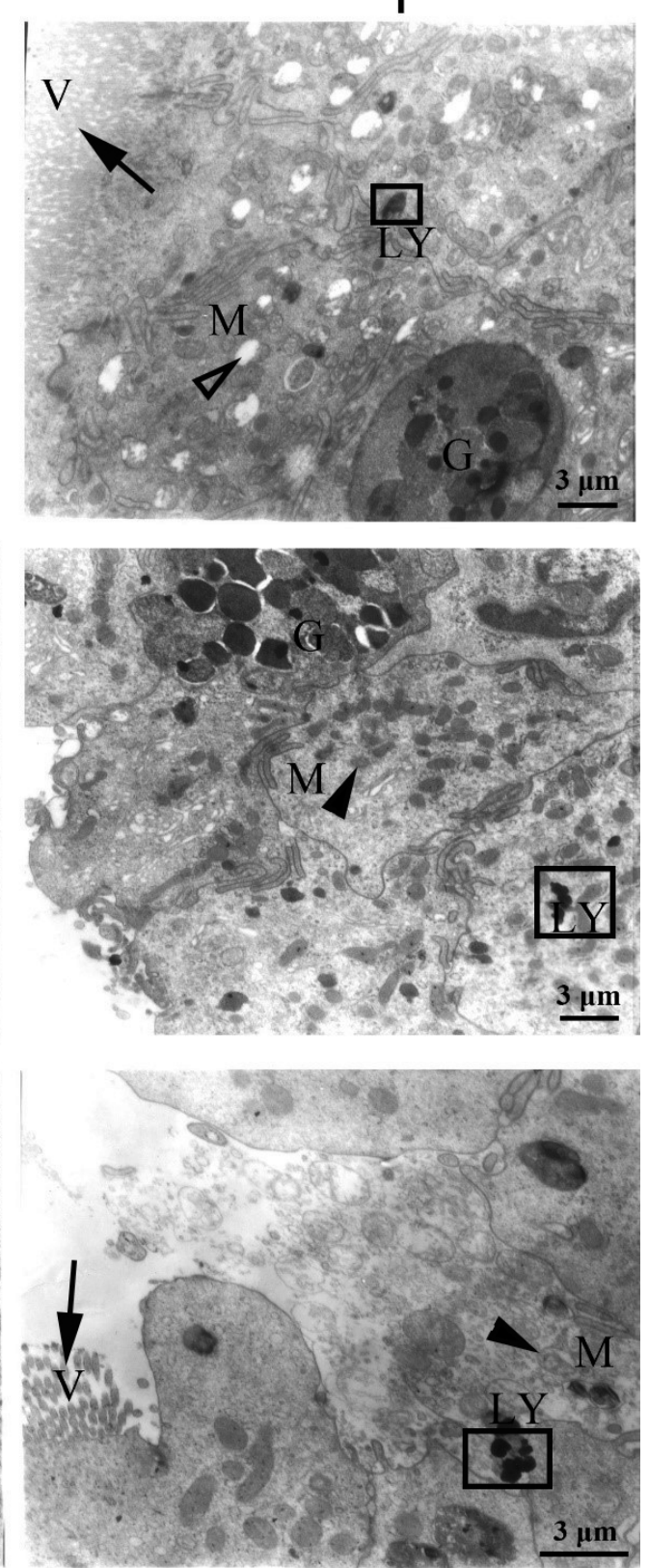

Figure 5. The representative ultrastructure of absorptive cells and goblet cells in the small intestine at 21 days of age. Note: M: mitochondria $(\boldsymbol{\Delta})$, V: microvilli $(\rightarrow)$, G: Goblet cells, LY: lysosomes $(\square)$, $\mathrm{N}$ : nucleus, JC: Junctional complexes $(\rightarrow)$, TW: terminal web. Scale bar $=3 \mu \mathrm{m}$. 


\subsection{Number of Goblet Cells Shown by Alcian Blue/PAS}

By Alcian Blue/PAS stain, goblet cells locating in mucosal epithelia and crypt were blue or purple in the small intestine of both groups. Compared with the control group, on day 7 , the number of goblet cells in jejunum of the $\mathrm{AFB}_{1}$ group was significantly decreased $(p<0.05)$. On days 14 and 21 , the numbers of goblet cells in the $\mathrm{AFB}_{1}$ group were evidently decreased $(p<0.05$ or $p<0.01)$ (Figures 6 and 7).

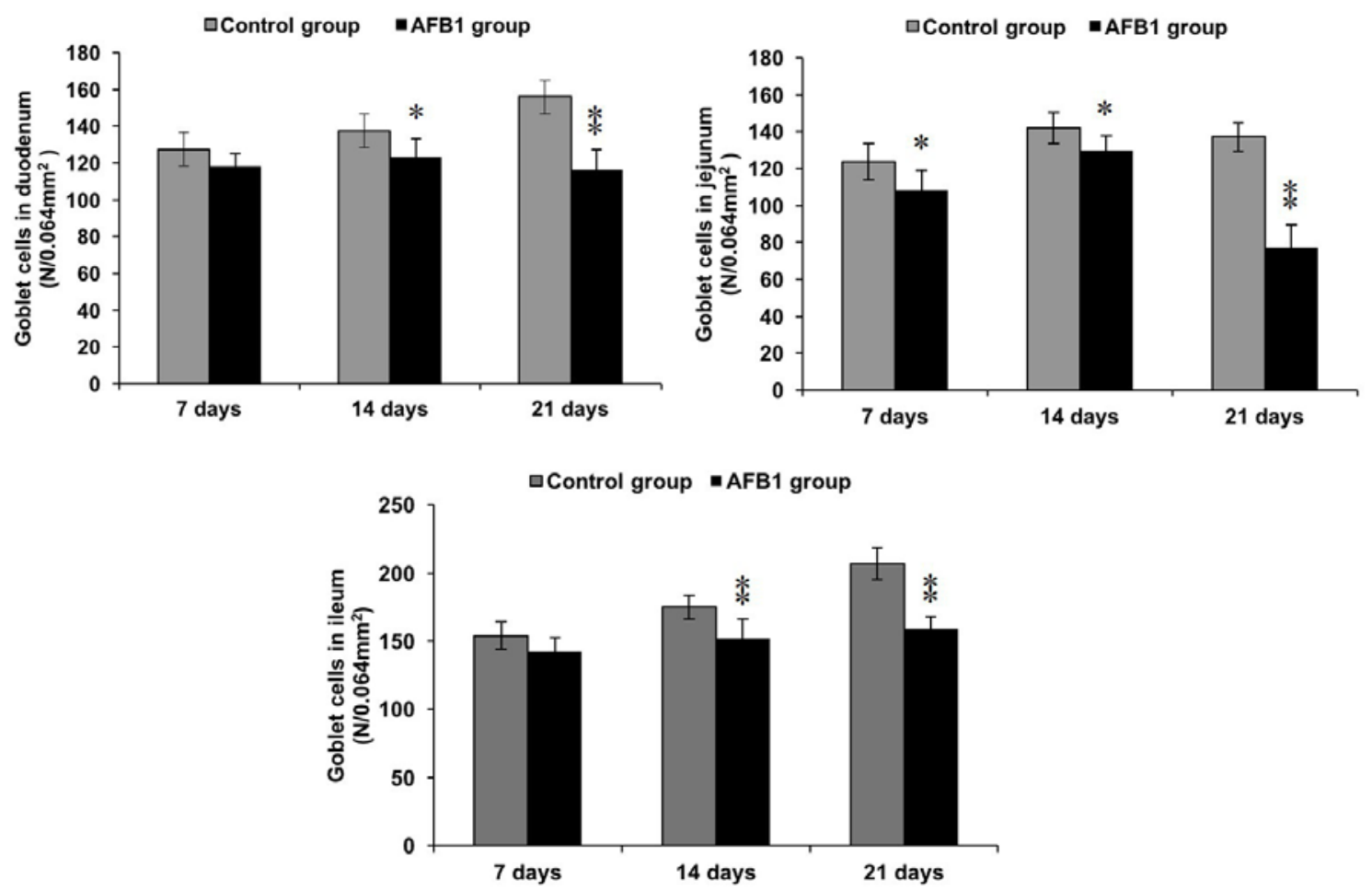

Figure 6. The numbers of goblet cells in the small intestine. Note: $0.064 \mathrm{~mm}^{2}$ was the area of one field under $400 \times$ magnification. ${ }^{*} p<0.05,{ }^{* *} p<0.01$.

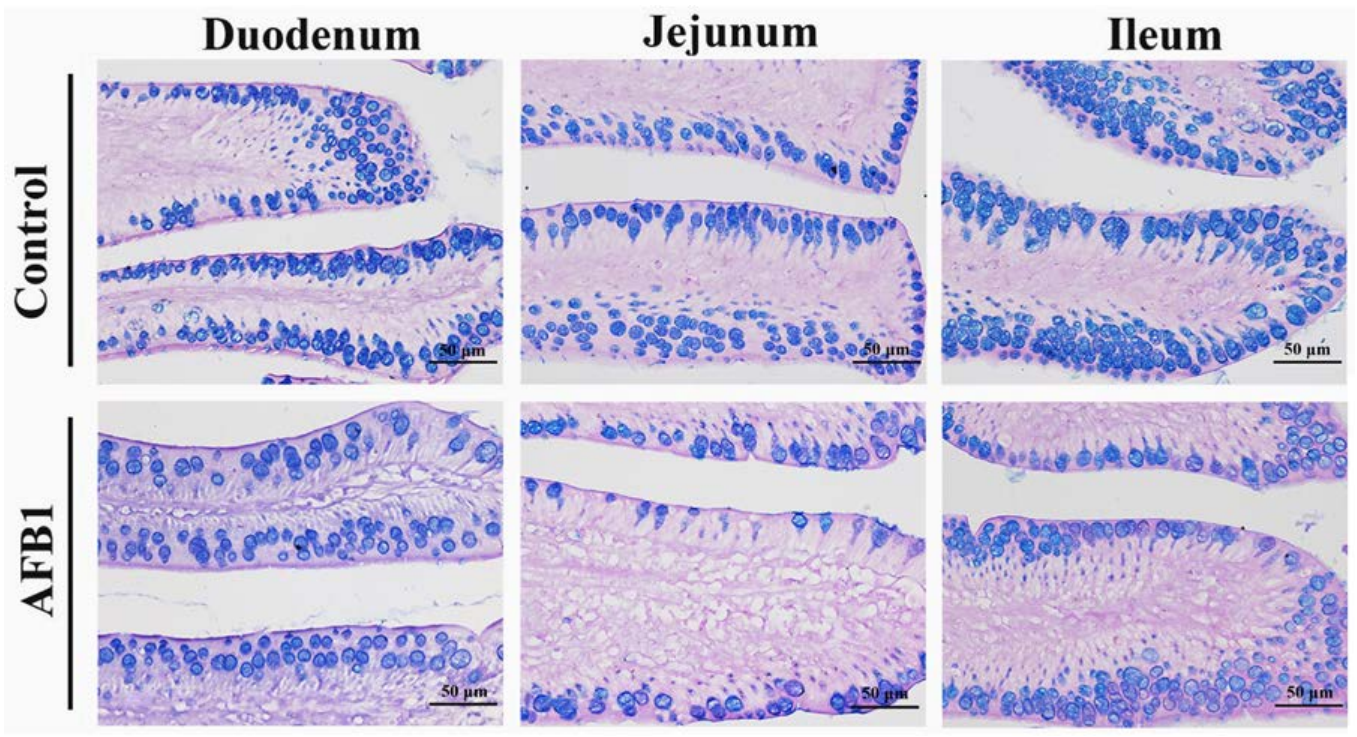

Figure 7. The representative goblet cells in the mucous epithelial cells of villi in the small intestine on day 21 (Alcian Blue/PAS stain, scale bar $=50 \mu \mathrm{m}$ ). 


\section{5. $m R N A$ Expression of TLR2-2, TLR-4 and TLR-7}

The mRNA expression of TLR2-2, TLR-4, and TLR7 in both the duodenum and jejunum in the $\mathrm{AFB}_{1}$ group significantly decreased in comparison to the control group on day 14 and 21 ( $p<0.05$ or $p<0.01$ ), except for duodenal TLR2-2 mRNA expression on day 14. The value of ileac TLR2-2 was evidently decreased in the $\mathrm{AFB}_{1}$ group on days 14 and $21(p<0.05$ or $p<0.01)$, and the values of ileac TLR-4 and TLR-7 in the AFB 1 group significantly declined during the experiment $(p<0.05$ or $p<0.01)$ (Figure 8).
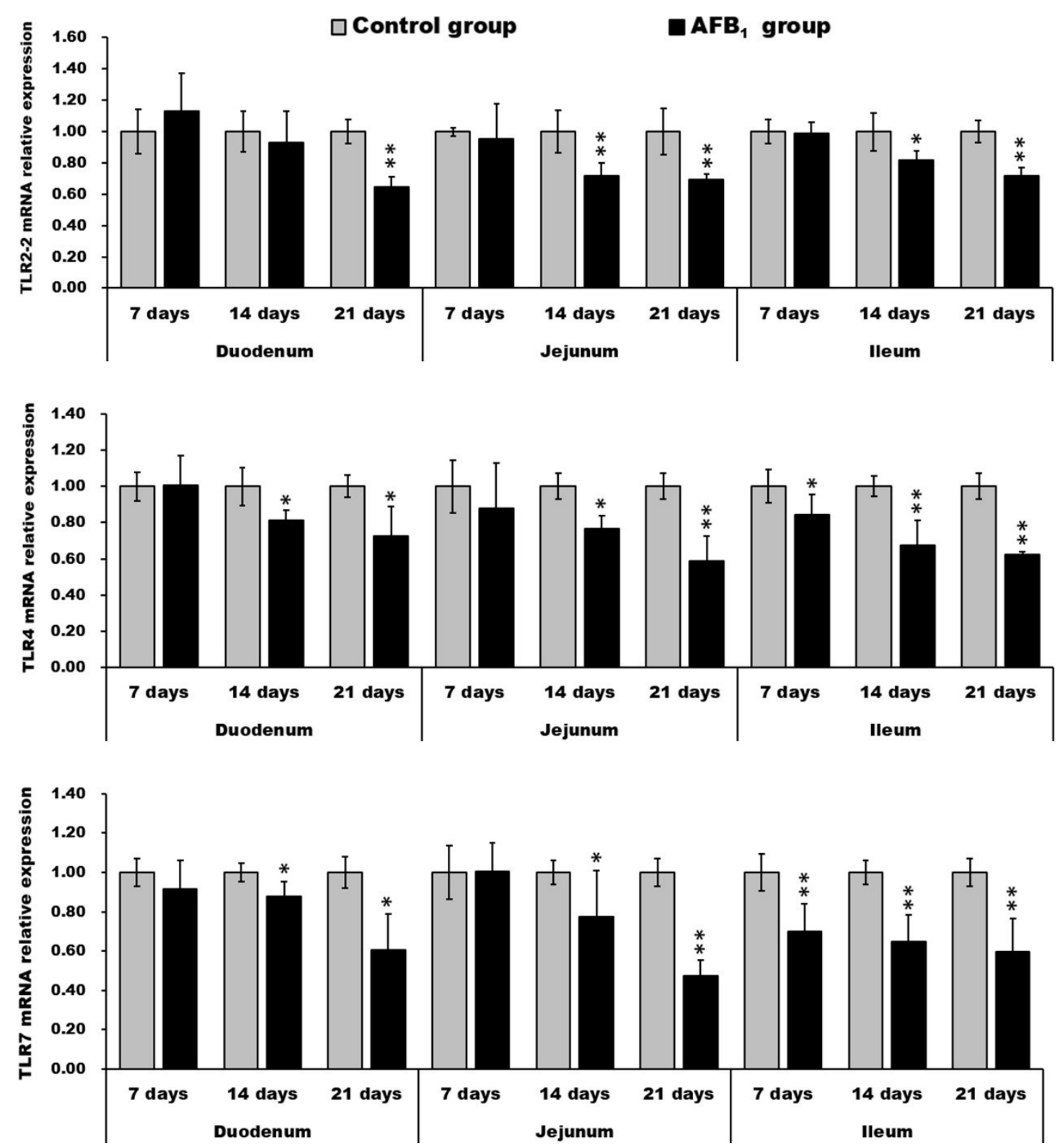

Figure 8. mRNA expression levels (fold of the control) of the TLR2-2, TLR4, and TLR7 in the small intestine. ${ }^{*} p<0.05,{ }^{* *} p<0.01$.

\section{Discussion}

Aflatoxin $B_{1}$, the most common aflatoxin, commonly contaminates various kinds of human food and animal feed elements in tropical and subtropical areas [10]. $\mathrm{AFB}_{1}$ can enter into animals and humans by consumption of $\mathrm{AFB}_{1}$-contaminated feed or food, so the gastrointestinal is the first 
site to contact $\mathrm{AFB}_{1}$, especially the small intestine [18]. The mucosal layer of the small intestine, including the lining epithelium, lamina propria with gland, and lamina muscularis, has the specificity to be structured in a way that provides a large surface, thus maximizing the absorption of nutrients. The surface of the mucosa is studded with finger-like projections, the intestinal villi, which are the most characteristic feature of the small intestine [29]. The crypts opening between the bases of the villi penetrate the mucosa as far as the lamina muscularis [29]. The intestinal villus and crypt play a crucial role in nutritional absorption and animal growth [30]. The continuous regeneration of the small intestinal epithelium is ensured by the migration of proliferating crypt cells up the villi [31]. Therefore, the height, width, and area of villus, but especially the area, are positively related with the absorptive efficiency of the small intestine in chickens, as well as epithelium thickness and villus:crypt ratio, while the crypt depth is negatively related. Our study showed decreased villus height and area as well as villus:crypt ratio in the three parts of the small intestine in the $\mathrm{AFB}_{1}$ group in comparison with the control chickens, suggesting that $\mathrm{AFB}_{1}$ reduced the small intestine's surface area for absorption in chickens. Our morphological measurements were similar to most previous studies, e.g., one in which Zhang et al. found that $0.3 \mathrm{mg} / \mathrm{kg} \mathrm{AFB}{ }_{1}$ could induce slightly decreased jejunal villus height and shedding of epithelial cells on the tip of the jejunal villus [25]; Aboutalebi reported that $0.7 \mathrm{mg} / \mathrm{kg}$ $\mathrm{AFB}_{1}$-treatment induced more serious damage in the duodenum than $0.35 \mathrm{mg} / \mathrm{kg} \mathrm{AFB}$-treatment [32]. Thus, $\mathrm{AFB}_{1}$ may have a dose-dependent effect. However, Feng et al. reported that $\mathrm{AFB}_{1}$ could increase the villus height and area in the duodenum and jejunum [33], which may result from differences in animal species and doses of $\mathrm{AFB}_{1}$ used for experiments.

In this study, moreover, $\mathrm{AFB}_{1}$ caused the shedding of the apical epithelia of villi in the small intestine, which was also observed by other researchers in chickens [18,25]. In murine models, $\mathrm{AFB}_{1}$ has been found to lead to pathological damage of the intestinal mucosa [34], and to decreased cell proliferation [35]. Furthermore, Akinrinmade et al. observed leucocyte, lymphocyte, and mononuclear cell infiltration in the lamina propria of rats when $\mathrm{AFB}_{1}$ was administered intraperitoneally [36], which was not observed in our study. These discrepancies may be attributed to different methods of administration and different animal models.

In addition, to explore the relationship between $\mathrm{AFB}_{1}$ and damage to absorptive cells in the small intestine, we used a transmission electron microscope to examine the ultrastructure of the epithelial cells of the small intestine following $\mathrm{AFB}_{1}$ exposure. In the duodenum, fewer mitochondrial cristae of absorptive cells and lysis of mitochondrial contents were observed in the $\mathrm{AFB}_{1}$ group. Also, microvilli on the surface of absorptive cells in the jejunum and ileum of the $\mathrm{AFB}_{1}$ group were decreased or shedding. Mitochondria play important roles not only in producing ATP, but in controlling apoptosis and contributing to the calcium homeostasis process of cells [37,38]. The involvement of microvilli has been established in various functions such as secretion, mechanotransduction, absorption, and cellular adhesion. Junctional complexes prevent fluid intestinal contents from diffusing into the lamina propria without going through the cells [29]. A terminal web is thought to be responsible for the movement of the microvilli. Damage to the mitochondria and microvilli, along with the disappearance of junctional complexes and the terminal web in some absorptive cells, induced by $\mathrm{AFB}_{1}$, showed that $\mathrm{AFB}_{1}$ could cause dysfunction of these structures, resulting in functional disorders of absorptive cells in the small intestine.

To further explore how $\mathrm{AFB}_{1}$ impaired the epithelial cells of small intestine, we investigated the number of goblet cells by Alcian Blue/PAS staining. Goblet cells are presumed to protect the mucous membrane in the intestine through the synthesis and secretion of several mediators, such as the mucin MUC2 and the small peptide trefoil factor $3[39,40]$. In this research, $\mathrm{AFB}_{1}$ could decrease the numbers of goblet cells, which may contribute to the damage to small intestine epithelia. Furthermore, the mucins production in goblet cells could be up-regulated by TNF- $\alpha$ [41]. Studies have showed that $\mathrm{AFB}_{1}$ inhibited the expression of cytokines in the small intestine, including TNF- $\alpha$ [14,42], by which we speculated that the contents of mucins secreted by goblet cells were depressed in the AFB 1 group. Moreover, goblet cells delivered luminal antigen to $\mathrm{CD}_{103^{+}}$dendric cells in the small intestine [43]. 
Thus, the decreased goblet cells caused by $\mathrm{AFB}_{1}$ may be associated with repressed immunity in the small intestine.

Previous in vivo research has shown that $\mathrm{AFB}_{1}$ impaired the adaptive immunity of the small intestine in chickens. Jiang et al. found that $\mathrm{AFB}_{1}$ decreased the $\mathrm{T}$ cell subset, cytokine expression, $\operatorname{IgA}^{+}$cell numbers, and the expression of immunoglobulin in the small intestine of broilers $[14,15]$. It is still unknown, however, whether $\mathrm{AFB}_{1}$ impaired the innate immunity of the small intestine of chickens in vivo. In this study, we determined the innate immunity of the small intestine of chickens through the expression levels of three toll-like receptors. By qRT-PCR, we found that the expression levels of TLR2-2, TLR4, and TLR7 mRNA were evidently suppressed by AFB 1 exposure, similarly to zearalenone-induced decrease of TLR-4 in IPEC-1 cells [26] and pig splenocyte [27], and to T2-toxin-induced decrease of TLR-7 in porcine alveolar macrophages [28]. However, mixed aflatoxins B and G could up-regulate TLR2 and TLR4 transcripts in human peripheral blood mononuclear cells [21]. These opposite results may be the consequence of the use of different cell types. Toll-like receptors, expressed on the membranes of immune and non-immune cells, assisted the immune system with the recognition of molecules shared by pathogens, and played vital roles in the innate immune system [44]. TLR2 mediated the host response to Gram-positive bacteria [45], and the functional properties of type 2 TLR2 (TLR2-2) were alike in chickens, humans, and mice [46]. TLR4 could identify lipopolysaccharides (LPS), various viral proteins, polysaccharides, and different kinds of endogenous proteins [47]. TLR7, recognizing single-stranded RNA of viruses such as $\mathrm{HCV}$, played a significant role in the regulation of antiviral immunity [48]. Based on the results of this research, we speculated that $\mathrm{AFB}_{1}$ may impair the innate immunity of the small intestine in chickens by depressing TLR2-2, TLR4, and TLR7 mRNA levels. Moreover, the activation of NF- $\mathrm{kB}$ in various cell types was triggered by the downstream signaling pathway of TLR2 and TLR4 $[49,50]$. Following NF- $\mathrm{KB}$ activation, various cytokines were released, like IL- 6 and TNF- $\alpha$ [51]. Our previous data demonstrated that $0.6 \mathrm{mg} / \mathrm{kg} \mathrm{AFB} 1$ in the broilers' diet could reduce the expression level of cytokine (like IL-2, IL-4, IL-6, IL-10, IL-17, IFN- $\gamma$, and TNF- $\alpha$ ) mRNA in the small intestine, implying that the immune function of the intestinal mucosa might be affected [14]. Therefore, the suppressed expression of TLR2 and TLR4 induced by AFB 1 may contribute to the decreased levels of various cytokines [14,42].

\section{Conclusions}

In conclusion, feed contaminated with $0.6 \mathrm{mg} / \mathrm{kg} \mathrm{AFB}_{1}$ could induce shedding of intestinal epithelial cells; decrease villus height and area, along with villus:crypt ratio; impair the microvilli and mitochondria of absorptive cells; decrease the goblet cell number; and depress the expression of TLR2-2, TLR4, and TLR7 in the chicken small intestine. These findings indicate that $\mathrm{AFB}_{1}$ may decrease the absorptive capacity and partially impair the innate immunity of the small intestine.

\section{Materials and Methods}

\subsection{Animals and Groups}

Ninety healthy male neonatal Cobb chickens, bought from the Chia Tai Group (Wenjiang, Sichuan, China), were randomized into control and $\mathrm{AFB}_{1}$ groups. There were three replicates/group and 15 animals/replicate. Housed in cages with electrically heated units for 21 days, chickens were provided with water as well as the aforementioned diet ad libitum. The animal protocols and all procedures of the experiment in this research were carried out according to the laws and guidelines of Animal Care and Use Committee of Sichuan Agricultural University (Approval No. 2012-024). As the chickens were fed with $\mathrm{AFB}_{1}$ after hatching, the day of age is the same as the day of the experiment.

\subsection{Diets}

According to the National Research Council (NRC, 1994) [52] and Chinese Feeding Standard of Chicken (NY/T33-2004), the basal diet was made the control diet. The $\mathrm{AFB}_{1}$ (Sigma-Aldrich, St. Louis, 
MO, USA, A6636) contaminated diet was formulated basically the same as reported earlier [53]. In short, after $27 \mathrm{mg} \mathrm{AFB}{ }_{1}$ farinose solid was completely dissolved into $30 \mathrm{~mL}$ methanol, the 30-mL mixture was mingled into $45 \mathrm{~kg}$ corn-soybean basal diet to formulate the $\mathrm{AFB}_{1}$ diet. For the control diet, equivalent methanol was also added into corn-soybean basal diet. Next, the methanol of both food supplies was evaporated at $98^{\circ} \mathrm{F}\left(37^{\circ} \mathrm{C}\right)$. Based on analyses by HPLC (Waters, Milford, MA, USA) with fluorescence detection (Waters, Model 2475, Milford, MA, USA), the $\mathrm{AFB}_{1}$ concentration was under $0.001 \mathrm{mg} / \mathrm{kg}$ in the control group, and $0.601 \mathrm{mg} / \mathrm{kg}$ in the $\mathrm{AFB}_{1}$ group, respectively.

\subsection{Histopathological Observation and Microscopic Analyses}

The duodenum, jejunum, and ileum from six broilers in each group were collected and fixed in $4 \%$ paraformaldehyde on days 7,14 , and 21 , and then were dehydrated and embedded in paraffin wax. The sample blocks were sectioned $(5 \mu \mathrm{m})$ with a microtome (Leica, Wetzlar, Germany, RM2135). The tissue sections were stained with hematoxylin and eosin $(\mathrm{H} \cdot \mathrm{E})$, and observed and photographed with a digital camera (Nikon DS-Ri1, Tokyo, Japan).

Five sections of each tissue in a chicken were taken, and five pictures $(400 \times)$ of each section were taken randomly. The epithelial thickness and villus height, width, and area, as well as crypt depth, were determined by image analysis software (Image-Pro Plus 5.1, Media Cybernetics, Inc., Rockville, MD, USA, 2006). The villus/crypt ratio was calculated by the following formula:

$$
\text { Villus } / \text { crypt ratio }=\frac{\text { villus height }}{\text { crypt depth }}
$$

\subsection{Transmission Electron Microscope Observation}

On day 21, three chickens from each group were humanely killed. At necropsy, the duodenum, jejunum, and ileum were carved into small pieces and immediately put into $2.5 \%$ glutaraldehyde for fixation, and in $2 \%$ veronal acetate-buffered $\mathrm{OsO}_{4}$ for post-fixation. After dehydrating in acetone gradient, the sample tissues were embedded in Epon 812. The sample blocks were sectioned $(65-75 \mathrm{~nm})$ in a microtome with a glass knife and put in uncoated copper grids. The tissue sections were stained with uranyl acetate and lead citrate. The ultrastructural architectures of the duodenum, jejunum, and ileum were observed by transmission electron microscope (Hitachi, H-600 transmission, Tokyo, Japan).

\subsection{Alcian Blue/Periodic Acid-Schiff (PAS) Stain}

De-waxed sections were stained in $1 \%$ Alcian blue for $5 \mathrm{~min}$, oxidized in $1 \%$ periodic acid, immersed in Schiff's reagent, and mounted and observed by light microscope. With each step, the section was washed in water. The stain showed the goblet cells containing acidic mucins (blue), neutral mucins (magenta), or mixtures of acidic and neutral mucins (purple). Five sections of each tissue in one bird were performed, and five pictures $(400 \times)$ of each section were taken randomly. The number of goblet cells was calculated on the tip of the villus and the principle for choosing goblet cells was to select the one with more secretion and intact section. All goblet cells in the pictures were counted for further analysis.

\section{6. $q R T-P C R$}

The small intestines from six chickens in each group on days 7, 14, and 21 were obtained and stored in liquid nitrogen. Then all samples were transferred and stored at $-80{ }^{\circ} \mathrm{C}$. Total RNA was extracted using TriPure isolation reagent (Roche Diagnostics $\mathrm{GmbH}$, Mannheim, Germany). The mRNA was reverse-transcribed into cDNA byTranscription First Strand cDNA Synthesis (Roche Diagnostics $\mathrm{GmbH}$ ). The cDNA was amplified with primers TLR2-2, 4, 7, and $\beta$-actin (specified in Table 1) using methods similar to those described by Jiang et al. [14]. Expression of TLR2-2, 4 and 7 transcripts is shown relative to that of $\beta$-actin using the $2^{-\Delta \Delta C t}$ method of Livak and Schmittgen [54]. 
Table 1. Primers of TLRs and house-keeping genes.

\begin{tabular}{|c|c|c|c|}
\hline Gene & Primer & Sequences $\left(5^{\prime}-3^{\prime}\right)$ & Accession Number \\
\hline \multirow{2}{*}{ TLR2-2 } & $\mathrm{F}$ & CTGGGAAGTGGATTGTGGAC & \multirow{2}{*}{ AB046533.2 } \\
\hline & $\mathrm{R}$ & CCAGCTCATACTTGCACCAC & \\
\hline \multirow{2}{*}{ TLR4 } & $\mathrm{F}$ & AGCTACGAGGTTCTGCTCCA & \multirow{2}{*}{ AY064697 } \\
\hline & $\mathrm{R}$ & TGTCCTGTGCATCTGAAAGC & \\
\hline \multirow{2}{*}{ TLR7 } & $\mathrm{F}$ & TTATGCCACTCСТСТСТАCCG & \multirow{2}{*}{ NM_001011688.2 } \\
\hline & $\mathrm{R}$ & GCAGCCACCTCTGAAAGATT & \\
\hline \multirow{2}{*}{$\beta$-actin } & $\mathrm{F}$ & TGCTGTGTTCCCATCTATCG & \multirow{2}{*}{ L08165 } \\
\hline & $\mathrm{R}$ & TTGGTGACAATACCGTGTTCA & \\
\hline
\end{tabular}

\subsection{Statistical Analysis}

The results were expressed as the mean \pm standard deviation, and the significant difference between the two groups was analyzed by variance analysis, which was performed by the independent sample test of SPSS 17.0 software for Windows. Differences were considered to be statistically significant at $p<0.05$.

Acknowledgments: This work was supported by the Huimin Project of Chengdu Science and Technology (2016-HM01-00337-SF).

Author Contributions: Jing Fang and Xi Peng conceived and designed the experiments; Fengyuan Wang, Kejie Chen, Caixia Gao, and Hetao Song performed the experiments; Fengyuan Wang, Kejie Chen, Zhicai Zuo, and Song Zhao analyzed the data; Ping Ouyang, Yi Zhou, Gang Shu, Bo Jing contributed reagents/materials/analysis tools; Fengyuan Wang and Kejie Chen wrote the paper; Jing Fang, Zhuangzhi Yang, Jianzhen Li and Hengmin Cui assisted with writing the manuscript.

Conflicts of Interest: The authors declare no conflict of interest.

\section{References}

1. Murphy, P.A.; Hendrich, S.; Landgren, C.; Bryant, C.M. Food mycotoxins: An update. J. Food Sci. 2006, 71, 51-65. [CrossRef]

2. Hernandez-Mendoza, A.; González-Córdova, A.F.; Vallejo-Cordoba, B.; Garcia, H.S. Effect of oral supplementation of Lactobacillus reuteri in reduction of intestinal absorption of aflatoxin $B_{1}$ in rats. J. Basic Microbiol. 2011, 51, 263-268. [CrossRef] [PubMed]

3. Vineis, P.; Xun, W. The emerging epidemic of environmental cancers in developing countries. Ann. Oncol. 2009, 20, 205-212. [CrossRef] [PubMed]

4. Teniola, O.D.; Addo, P.A.; Brost, I.M.; Färber, P.; Jany, K.D.; Alberts, J.F.; van Zyl, W.H.; Steyn, P.S.; Holzapfel, W.H. Degradation of aflatoxin $B_{1}$ by cell-free extracts of Rhodococcus erythropolis and Mycobacterium fluoranthenivorans sp. nov. DSM44556(T). Int. J. Food Microbiol. 2005, 105, 111-117. [CrossRef] [PubMed]

5. Hedayati, M.T.; Pasqualotto, A.C.; Warn, P.A.; Bowyer, P.; Denning, D.W. Aspergillus flavus: Human pathogen, allergen and mycotoxin producer. Microbiology 2007, 153, 1677-1692. [CrossRef] [PubMed]

6. Bhat, R.V.; Vasanthi, S.; Rao, B.S.; Rao, R.N.; Rao, V.S.; Nagaraja, K.V.; Bai, R.G.; Prasad, C.A.K.; Vanchinathan, S.; Roy, R.; et al. Aflatoxin $B_{1}$ contamination in maize samples collected from different geographical regions of India-A multicentre study. Food Addit. Contam. 1997, 14, 151-156. [CrossRef] [PubMed]

7. Bababunmi, E.A.; Uwaifo, A.O.; Bassir, O. Hepatocarcinogens in Nigerian foodstuffs. World Rev. Nutr. Diet. 1978, 28, 188-209. [PubMed]

8. Shivachandra, S.B.; Sah, R.L.; Singh, S.D.; Kataria, J.M.; Manimaran, K. Immunosuppression in broiler chicks fed aflatoxin and inoculated with fowl adenovirus serotype-4 (FAV-4) associated with hydropericardium syndrome. Vet. Res. Commun. 2003, 27, 39-51. [CrossRef] [PubMed] 
9. Peng, X.; Chen, K.; Chen, J.; Fang, J.; Cui, H.; Zuo, Z.; Deng, J.; Chen, Z.; Geng, Y.; Lai, W. Aflatoxin B 1 affects apoptosis and expression of Bax, Bcl-2, and Caspase-3 in thymus and bursa of fabricius in broiler chickens. Environ. Toxicol. 2015, 30, 1113-1120. [CrossRef] [PubMed]

10. Yunus, A.W.; Razzazi-Fazeli, E.; Bohm, J. Aflatoxin $B_{1}$ in affecting broiler's performance, immunity, and gastrointestinal tract: A review of history and contemporary issues. Toxins 2011, 3, 566-590. [CrossRef] [PubMed]

11. De Kivit, S.; Tobin, M.C.; Forsyth, C.B.; Keshavarzian, A.; Landay, A.L. Regulation of intestinal immune responses through TLR activation: Implications for pro- and prebiotics. Front. Immunol. 2014, 5, 60. [CrossRef] [PubMed]

12. Linden, S.K.; Sutton, P.; Karlsson, N.G.; Korolik, V.; McGuckin, M.A. Mucins in the mucosal barrier to infection. Mucosal Immunol. 2008, 1, 183-197. [CrossRef] [PubMed]

13. Salzman, N.H.; Hung, K.; Haribhai, D.; Chu, H.; Karlsson-Sjöberg, J.; Amir, E.; Teggatz, P.; Barman, M.; Hayward, M.; Eastwood, D.; et al. Enteric defensins are essential regulators of intestinal microbial ecology. Nat. Immunol. 2010, 11, 76-83. [CrossRef] [PubMed]

14. Jiang, M.; Peng, X.; Fang, J.; Cui, H.; Yu, Z.; Chen, Z. Effects of aflatoxin $B_{1}$ on T-cell subsets and mRNA expression of cytokines in the intestine of broilers. Int. J. Mol. Sci. 2015, 16, 6945-6959. [CrossRef] [PubMed]

15. Jiang, M.; Fang, J.; Peng, X.; Cui, H.; Yu, Z. Effect of aflatoxin $\mathrm{B}_{1}$ on $\mathrm{IgA}^{+}$cell number and immunoglobulin mRNA expression in the intestine of broilers. Immunopharmacol. Immunotoxicol. 2015, 37, 450-457. [CrossRef] [PubMed]

16. Kana, J.R.; Teguia, A.; Choumboue, J.T. The evaluation of activated dietary charcoal from Canarium schweinfurthii Engl. seed and maize cob as toxin binder in broiler chickens. Adv. Anim. Biosci. 2010, 1, 467-468. [CrossRef]

17. Yunus, A.W.; Ghareeb, K.; Abd-El-Fattah, A.A.; Twaruzek, M.; Böhm, J. Gross intestinal adaptations in relation to broiler performance during chronic aflatoxin exposure. Poult. Sci. 2011, 90, 1683-1689. [CrossRef] [PubMed]

18. Grozeva, N.; Valchev, I.; Hristov, T.; Lazarov, L.; Nikolov, Y. Histopathological changes in small intestines of broiler chickens with experimental aflatoxicosis. Agric. Sci. Technol. 2015, 7, 319-323.

19. Ledoux, D.R.; Rottinghaus, G.E.; Bermudez, A.J.; Alonso-Debolt, M. Efficacy of a hydrated sodium calcium aluminosilicate to ameliorate the toxic effects of aflatoxin in broiler chicks. Poult. Sci. 1999, 78, 204-210. [CrossRef] [PubMed]

20. Takeuchi, O.; Akira, S. Pattern recognition receptors and inflammation. Cell 2010, 140, 805-820. [CrossRef] [PubMed]

21. Malvandi, A.M.; Mehrzad, J.; Saleh-Moghaddam, M. Biologically relevant doses of mixed aflatoxins B and G up-regulate MyD88, TLR2, TLR4 and CD14 transcripts in human PBMCs. Immunopharmacol. Immunotoxicol. 2013, 35, 528-532. [CrossRef] [PubMed]

22. Sugiyama, K.; Muroi, M.; Kinoshita, M.; Hamada, O.; Minai, Y.; Sugita-Konishi, Y.; Kamata, Y.; Tanamoto, K. NF- $\mathrm{BB}$ activation via MyD88-dependent Toll-like receptor signaling is inhibited by trichothecene mycotoxin deoxynivalenol. J. Toxicol. Sci. 2016, 41, 273-279. [CrossRef] [PubMed]

23. Yu, Z.; Chen, J.; Peng, X.; Fang, J.; Chen, K.; Yang, H. Effect of aflatoxin $B_{1}$ pathological changes of immune organs in broilers. Acta Vet. Zootech. Sin. 2015, 46, 1447-1454. [CrossRef]

24. Chen, J.; Chen, K.; Yuan, S.; Peng, X.; Fang, J.; Wang, F.; Cui, H.; Chen, Z.; Yuan, J.; Geng, Y. Effects of aflatoxin $\mathrm{B}_{1}$ on oxidative stress markers and apoptosis of spleens in broilers. Toxicol. Ind. Health 2016, 32, 278-284. [CrossRef] [PubMed]

25. Zhang, S.; Peng, X.; Fang, J.; Cui, H.; Zuo, Z.; Chen, Z. Effects of aflatoxin $B_{1}$ exposure and sodium selenite supplementation on the histology, cell proliferation, and cell cycle of jejunum in broilers. Biol. Trace Elem. Res. 2014, 160, 32-40. [CrossRef] [PubMed]

26. Taranu, I.; Marin, D.E.; Pistol, G.C.; Motiu, M.; Pelinescu, D. Induction of pro-inflammatory gene expression by Escherichia coli and mycotoxin zearalenone contamination and protection by a lactobacillus mixture in porcine IPEC-1 cells. Toxicon 2015, 97, 53. [CrossRef] [PubMed]

27. Pistol, G.C.; Braicu, C.; Motiu, M.; Gras, M.A.; Marin, D.E.; Stancu, M.; Calin, L.; Israel-Roming, F.; Berindan-Neagoe, I.; Taranu, I. Zearalenone mycotoxin affects immune mediators, MAPK signalling molecules, nuclear receptors and genome-wide gene expression in pig spleen. PLoS ONE 2015, 10, e0127503. [CrossRef] [PubMed] 
28. Seeboth, J.; Solinhac, R.; Oswald, I.P.; Guzylack-Piriou, L. The fungal T-2 toxin alters the activation of primary macrophages induced by TLR-agonists resulting in a decrease of the inflammatory response in the pig. Vet. Res. 2012, 43, 35. [CrossRef] [PubMed]

29. Jo, A.E.; Brian, L.F. Dellmann's Textbook of Veterinary Histology; Blackwell Publishing Professional: Ames, IA, USA, 2006, ISBN 0781741483.

30. Hernández, F.; García, V.; Madrid, J.; Orengo, J.; Catalá, P.; Megías, M.D. Effect of formic acid on performance, digestibility, intestinal histomorphology and plasma metabolite levels of broiler chickens. Br. Poult. Sci. 2006, 47, 50-56. [CrossRef] [PubMed]

31. Geyra, A.; Uni, Z.; Sklan, D. Enterocyte dynamics and mucosal development in the posthatch chick. Poult. Sci. 2001, 80, 776-782. [CrossRef] [PubMed]

32. Aboutalebi, N. Toxic effects of aflatoxin $\mathrm{B}_{1}$ on duodenum tissue. J. Am. Sci. 2013, 9, 115-117.

33. Feng, G.D.; He, J.; Ao, X.; Chen, D.W. Effects of maize naturally contaminated with aflatoxin $B_{1}$ on growth performance, intestinal morphology, and digestive physiology in ducks. Poult. Sci. 2017, 96, 1948-1955. [CrossRef] [PubMed]

34. Gaikwad, S.S.; Pillai, M.M. Effect of aflatoxin $B_{1}$ in gastrointestine of mice. J. Ecophysiol. Occup. Health 2004, 4, 153-159.

35. Fleming, S.E.; Youngman, L.D.; Ames, B.N. Intestinal cell proliferation is influenced by intakes of protein and energy, aflatoxin, and whole-body radiation. Nutr. Cancer 1994, 22, 11-30. [CrossRef] [PubMed]

36. Akinrinmade, F.J.; Akinrinde, A.S.; Amid, A. Changes in serum cytokine levels, hepatic and intestinal morphology in aflatoxin $\mathrm{B}_{1}$-induced injury: Modulatory roles of melatonin and flavonoid-rich fractions from Chromolena odorata. Mycotoxin Res. 2016, 32, 53-60. [CrossRef] [PubMed]

37. Jiang, X.; Wang, X. Cytochrome C-mediated apoptosis. Annu. Rev. Biochem. 2004, 73, 87-106. [CrossRef] [PubMed]

38. Santulli, G.; Xie, W.; Reiken, S.R.; Marks, A.R. Mitochondrial calcium overload is a key determinant in heart failure. Proc. Natl. Acad. Sci. USA 2015, 112, 11389-11394. [CrossRef] [PubMed]

39. Moncada, D.M.; Kammanadiminti, S.J.; Chadee, K. Mucin and toll-like receptors in host defense against intestinal parasites. Trends Parasitol. 2003, 19, 305-311. [CrossRef]

40. Taupin, D.; Podolsky, D.K. Trefoil factors: Initiators of mucosal healing. Nat. Rev. Mol. Cell Biol. 2003, 4, 721-732. [CrossRef] [PubMed]

41. Andrianifahanana, M.; Moniaux, N.; Batra, S.K. Regulation of mucin expression: Mechanistic aspects and implications for cancer and inflammatory diseases. Biochim. Biophys. Acta 2006, 1765, 189-222. [CrossRef] [PubMed]

42. He, Y.; Fang, J.; Peng, X.; Cui, H.; Zuo, Z.; Deng, J.; Chen, Z.; Lai, W.; Shu, G.; Tang, L. Effects of sodium selenite on aflatoxin $B_{1}$-induced decrease of ileac T cell and the mRNA contents of IL-2, IL-6, and TNF- $\alpha$ in broilers. Biol. Trace Elem. Res. 2014, 159, 167-173. [CrossRef] [PubMed]

43. McDole, J.R.; Wheeler, L.W.; McDonald, K.G.; Wang, B.; Konjufca, V.; Knoop, K.A.; Newberry, R.D.; Miller, M.J. Goblet cells deliver luminal antigen to $\mathrm{CD}_{103^{+}}$dendritic cells in the small intestine. Nature 2012, 483, 345-349. [CrossRef] [PubMed]

44. Delneste, Y.; Beauvillain, C.; Jeannin, P. Innate immunity: Structure and function of TLRs. Med. Sci. 2007, 23, 67-73. [CrossRef]

45. Borrello, S.; Nicolò, C.; Delogu, G.; Pandolfi, F.; Ria, F. TLR2: A crossroads between infections and autoimmunity? Int. J. Immunopathol. Pharmacol. 2011, 24, 549-556. [CrossRef] [PubMed]

46. Fukui, A.; Inoue, N.; Matsumoto, M.; Nomura, M.; Yamada, K.; Matsuda, Y.; Toyoshima, K.; Seya, T. Molecular cloning and functional characterization of chicken toll-like receptors. A single chicken toll covers multiple molecular patterns. J. Biol. Chem. 2001, 276, 47143-47149. [CrossRef] [PubMed]

47. Brubaker, S.W.; Bonham, K.S.; Zanoni, I.; Kagan, J.C. Innate immune pattern recognition: A cell biological perspective. Annu. Rev. Immunol. 2015, 33, 257-290. [CrossRef] [PubMed]

48. Zhang, Y.; El-Far, M.; Dupuy, F.P.; Abdel-Hakeem, M.S.; He, Z.; Procopio, F.A.; Shi, Y.; Haddad, E.K.; Ancuta, P.; Sekaly, R.P.; et al. HCV RNA Activates APCs via TLR7/TLR8 while virus selectively stimulates macrophages without inducing antiviral responses. Sci. Rep. 2016, 6, 29447. [CrossRef] [PubMed]

49. Medzhitov, R.; Janeway, C., Jr. Innate immunity. N. Engl. J. Med. 2000, 343, 338-344. [CrossRef] [PubMed]

50. Anderson, K.V. Toll signaling pathways in the innate immune response. Curr. Opin. Immunol. 2000, 12, 13-19. [CrossRef] 
51. Thoma-Uszynski, S.; Stenger, S.; Takeuchi, O.; Ochoa, M.T.; Engele, M.; Sieling, P.A.; Barnes, P.F.; Rollinghoff, M.; Bolcskei, P.L.; Wagner, M.; et al. Induction of direct antimicrobial activity through mammalian toll-like receptors. Science 2001, 291, 1544-1547. [CrossRef] [PubMed]

52. National Research Council. Nutrient Requirement of Poultry, 9th ed.; National Academy Press: Washington, DC, USA, 1994, ISBN 978-0-309-04892-7.

53. Kaoud, H.A. Innovative methods for the amelioration of aflatoxin $\left(\mathrm{AFB}_{1}\right)$ effect in broiler chicks. Spec. J. Biol. Sci. 2015, 1, 19-24.

54. Livak, K.J.; Schmittgen, T.D. Analysis of relative gene expression data using real-time quantitative PCR and the 2(-Delta Delta C(T)) method. Methods 2012, 25, 402-408. [CrossRef] [PubMed]

(C) 2018 by the authors. Licensee MDPI, Basel, Switzerland. This article is an open access article distributed under the terms and conditions of the Creative Commons Attribution (CC BY) license (http:/ / creativecommons.org/licenses/by/4.0/). 